\title{
Uji Potensi Epigallocatechin Gallate Kulit Pisang Raja (Musa paradisiaca var. Raja) terhadap Caspase 3 melalui Granzyme B Pathway pada Mencit (Mus musculus) Model Sepsis Berbasis in Silico
}

\author{
Lisa Savitri $^{1^{*}}$, Elfred Rinaldo Kasimo ${ }^{2}$, Lian Pandu Farendra ${ }^{3}$, Iza Dwi Muslikha ${ }^{4}$ \\ 1,2,3,4 Program Studi Teknologi Laboratorium Medis, Universitas Kadiri, Jalan Selomangleng no. 1 Kota Kediri \\ *Correspondence email: lisasavitri@unik-kediri.ac.id
}

\begin{abstract}
Abstrak. Kulit buah pisang masak yang berwarna kuning kaya akan senyawa flavonoid, serta mengandung senyawa fenolik lainnya. Adanya flavonoid dan senyawa fenolik lainnya pada kulit pisang perlu diidentifikasi dan diuji aktivitasnya, sehingga dapat meningkatkan pemanfaatan limbah buah pisang lebih optimal. Selain itu pisang juga memiliki kandungan epigallocatechin gallate (EGCG) yang tinggi. EGCG terkenal dengan spektrum yang luas dari aktivitas biologis sebagai agen anti-oksidatif, antiinflamasi, dan anti-tumor. Tujuan penelitian ini adalah untuk mengetahui potensi EGCG kulit pisang raja (Musa paradisiaca var. Raja) terhadap caspase 3 melalui granzyme B pathway pada mencit (Mus musculus) model sepsis berbasis in silico. Analisis potensi EGCG terhadap mencit dilakukan dengan menggunakan aplikasi http://stitch.embl.de/. STITCH adalah database interaksi yang diketahui dan diprediksi antara bahan kimia dan protein. Interaksi meliputi asosiasi langsung (fisik) dan tidak langsung (fungsional), data STITCH berasal dari prediksi komputasi, dari transfer pengetahuan antara organisme, dan dari interaksi yang dikumpulkan dari database (primer) lainnya. Analisis mekanisme epigallocatechin gallate kulit pisang raja terhadap capase 3 pada mencit model sepsis menggunakan aplikasi bioinformatika https://www.kegg.jp/. Berdasarkan hasil analisis dapat diketahui bahwa EGCG dapat dijadikan sebagai kandidat target agen yang menjanjikan untuk protein membran plasma, seperti reseptor faktor pertumbuhan epidermal. Selain itu, telah ditunjukkan mekanisme aksi yang mengandalkan penghambatan ERK1/2, p38 MAPK, NF-кB, dan faktor pertumbuhan endotel vaskular. Selanjutnya, EGCG dan turunannya digunakan dalam penghambatan proteasome dan mereka terlibat dalam mekanisme epigenetik.
\end{abstract}

Kata kunci: caspase 3; epigallocatechin gallate; granzyme B pathway; sepsis

\begin{abstract}
Yellow ripe banana skin is rich in flavonoid compounds, and contains other phenolic compounds. The presence of flavonoids and other phenolic compounds in banana peels needs to be identified and tested for their activities, so as to increase the utilization of banana waste more optimally. Besides bananas also contain high epigallocatechin gallate (EGCG). EGCG is well known for its wide spectrum of biological activity as an anti-oxidative, anti-inflammatory and anti-tumor agent. The purpose of this study was to determine the potential of EGCG of plantain (Musa paradisiaca var. Raja) peel against caspase 3 through granzyme B pathway in mice (Mus musculus) sepsis model based on silico. Analysis of the potential of EGCG on mice was carried out using the application http://stitch.embl.de/. STITCH is a database of known and predicted interactions between chemicals and proteins. Interactions include direct (physical) and indirect (functional) associations, STITCH data derived from computational predictions, from the transfer of knowledge between organisms, and from interactions collected from other (primary) databases. Analysis of the mechanism of epigallocatechin gallate of plantain peel against capase 3 in sepsis mice using bioinformatics application https://www.kegg.jp/. Based on the results of the analysis it can be seen that EGCG can be used as a promising target agent candidate for plasma membrane proteins, such as epidermal growth factor receptors. In addition, action mechanisms have been demonstrated that rely on inhibition of ERK1 /2, p38 MAPK, NF- $\kappa B$, and vascular endothelial growth factors. Furthermore, EGCG and its derivatives are used in proteasome inhibition and they are involved in epigenetic mechanisms.
\end{abstract}

Keywords: caspase 3; epigallocatechin gallate; granzyme B pathway; sepsis

\section{PENDAHULUAN}

Sepsis adalah disfungsi organ yang mengancam jiwa yang terjadi dari respons tubuh terhadap infeksi. Sepsis membutuhkan penggunaan antibiotik yang sesuai untuk mengendalikan sumber infeksi. Dengan manajemenyang sesuai dengan perawatan protokol yang mendukung perawatan biasa yang tepat, pemahaman fisiologi sepsis dan pedoman praktik terbaik sangat penting (Dugar, et al., 2020). Sepsis memiliki tingkat kejadian yang tinggi, hal tersebut didukung oleh penelitian mengenai tingkat penyebaran sepsis di ICU RSUP Prof. Dr. R. D. Kandou Manado yang mendapatkan hasil bahwa terdapat $27,08 \%$ penderita sepsis berat, $14,58 \%$ penderita syok septik, dan 58,33\% penderita sepsis (Tambajong, et al., 2016).

Lipopolisakarida (LPS) terdiri dari polisakarida hidrofilik dan komponen hidrofobik yang dikenal sebagai lipid A yang bertanggung jawab atas bioaktivitas utama endotoksin. LPS dapat dikenali oleh sel-sel imun sebagai molekul yang berhubungan dengan patogen melalui reseptor seperti Toll Like Receptors (TLR) 4. Sebagian besar enzim dan gen yang berkaitan dengan biosintesis dan ekspor lipopolisakarida telah diidentifikasi dalam Escherichia coli, dan mereka terbagi oleh sebagian besar bakteri Gram-negatif berdasarkan pada informasi genetik yang tersedia. Namun, struktur terperinci dari LPS berbeda dari satu bakteri ke bakteri 
lain, menunjukkan bahwa enzim tambahan yang dapat memodifikasi struktur dasar LPS ada pada bakteri, terutama beberapa patogen. Modifikasi struktural LPS ini kadang-kadang diatur dengan ketat. Mereka tidak diperlukan untuk bertahan hidup tetapi terkait erat dengan virulensi bakteri (Wang dan Quinn, 2010).

Pengenalan LPS oleh TLR4 memulai respons inflamasi yang menginduksi imunitas antimikroba yang kuat. Namun, tidak terkendali respons peradangan dapat merusak. Untuk mencegah perkembangan syok septik selama infeksi dengan Bakteri Gram-negatif, sistem kekebalan tubuh telah mengembangkan mekanisme untuk menetralisir LPS oleh protein khusus. Dalam penelitian ini yang telah dilakukan oleh Wittmann, et al. (2020) dilaporkan bahwa ekspresi rekombinan dan karakterisasi fungsional homolog tikus peningkatan Bactericidal/Permeability-Increasing Protein (BPI). BPI tikus rekombinan yang dimurnikan mampu menetralkan aktivasi makrofag yang dimediasi LPS dan memblok pematangan sel dendritik bergantung pada LPS. BPI tikus rekombinan menetralkan kapasitas bakteri Gramnegatif mengaktifkan sel-sel kekebalan, tetapi tidak mempengaruhi sifat stimulasi bakteri Gram-positif.

Gambar mikroskop elektron menunjukkan bahwa peptida menghancurkan struktur LPS. Penghambatan aktivitas antibakteri defensin asli dan analog di hadapan LPS menunjukkan bahwa interaksi awal dengan permukaan bakteri serupa. Urutan atau struktur defensin asli juga tidak penting, meskipun muatan kationik diperlukan untuk mengikat ke LPS. Interaksi hidrofobik adalah kekuatan pendorong utama untuk asosiasi polimiksin B non-ribosom yang disintesis, alamethicin, gramicidin A, dan gramicidin S dengan LPS. Sangat mungkin bahwa peptida ini dengan cepat memasukkan ke dalam membran dan tidak berinteraksi dengan permukaan sel bakteri, sedangkan peptida kationik seperti $\beta$-defensin dan analognya, melittin dan LL37, pertama-tama berinteraksi dengan permukaan sel bakteri dan kemudian membran. Hasil kami menunjukkan bahwa mengevaluasi interaksi peptida antibakteri dan hemolitik dengan LPS adalah cara yang meyakinkan untuk menjelaskan mekanisme pembunuhan bakteri atau hemolisis (Krishnakumari, et al., 2020)

Apoptosis umumnya terlibat dalam infeksi bakteri dan patogenesis. Selama infeksi bakteri, faktor virulen (kebanyakan endotoksin) diproduksi dan disekresikan dari patogen dan memicu sinyal apoptosis. Secara umum sel mengalami apoptosis melalui dua jalur utama, yaitu jalur ekstrinsik (jalur reseptor kematian) dan jalur intrinsik (jalur mitokondria). Diperkirakan bahwa penghambatan sinyal apoptosis dapat memberikan perlindungan terhadap infeksi bakteri yang disebabkan sepsis. Jalur ekstrinsik umumnya diprakarsai oleh aktivasi reseptor kematian melalui interaksi antara ligan alami atau dengan menginduksi klusterifikasi reseptor kematian. Reseptor kematian adalah reseptor permukaan yang menjadi anggota keluarga Tumor Necrosis Factor
(TNF) dan berinteraksi dengan ligannya untuk membentuk kompleks reseptor kematian (Lin, et al., 2010). Reseptor kematian memainkan peran penting dalam apoptosis dan dapat mengaktifkan sebuah cascade caspase dalam beberapa detik dari ikatan ligan. Oleh karena itu, induksi apoptosis melalui mekanisme ini berlangsung sangat cepat (Ghatage, et al., 2013).

Mekanisme lain dari apoptosis yang tergantung caspase adalah jalur intrinsik. Apoptosis melalui jalur ini diinduksi oleh sinyal intraselular, seperti hipoksia, radiasi, infeksi virus, dan terutama adalah kerusakan DNA. Keluarga protein Bcl-2 adalah mediator utama proses ini. Setelah mengeluarkan protein spesifik proapoptosis, seperti sitokrom c, smac/DIABLO, AIF, dan Endo $G$, jalur eksekusi diakhiri dengan aktivasi caspase 3 (Ghatage, et al., 2013).

Semua caspases disintesis dalam sel sebagai zymogens yang tidak aktif secara katalitis dan harus menjalani proses aktivasi. Aktivasi efektor caspase seperti caspase 3 atau caspase 7, dilakukan oleh inisiator caspase, seperti caspase 9. Inisiator caspase adalah autoactivated di bawah kondisi apoptosis, yaitu proses yang biasanya membutuhkan dan difasilitasi oleh kompleks multi komponen, misalnya apoptosome yang bertanggung jawab untuk aktivasi caspase 9. Penelitian mengenai caspase 3 dianggap penting, karena caspase 3 merupakan efektor caspase terpenting yang bertanggungjawab atas morfologi dan perubahan biologis yang terlihat pada sel apoptosis (Ghatage, et al., 2013), walaupun caspase 6 dan 7 merupakan efektor caspase, namun letak jalur caspase tersebut berada di awal, sehingga masih terdapat kemungkinan walaupun caspase tersebut teraktivasi, namun akhirnya apoptosis gagal terjadi dikarenakan rilisnya protein $\mathrm{Bcl}-2$ antiapoptosis yang dapat menghambat apoptosis.

Sepsis merupakan masalah klinis yang penting meskipun telah terjadi kemajuan terapi. Sepsis dapat diperberat oleh peningkatan kuman yang multiresisten terhadap bermacam antibiotik, sehingga sangat diperlukan kombinasi antibiotik dalam penatalaksanaan sepsis. Adanya perkembangan ilmu pengetahuan menyebabkan manusia mampu mengisolasi senyawa kimia dari tumbuhan untuk keperluan pengobatan. Faktor ini yang mendorong orang untuk mencari obat alternatif yang lebih aman, yaitu kembali ke alam dengan memanfaatkan tumbuhan sebagai obat tradisional yang secara empirik dapat menurunkan terjadinya apoptosis. Indonesia merupakan salah satu negara yang memiliki potensi dalam bidang pertanian. Banyaknya potensi dalam bidang pertanian menyebabkan banyaknya limbah yang dihasilkan baik pada saat panen maupun pascapanen. Limbah secara umum yang sering di hasilkan dalam bidang pertanian antara lain cangkang pala, daun cengkeh, kulit durian, kulit kacang, kulit pisang, sabut kelapa, dan sekam padi (Dawanaka, et al., 2015). 
Tanaman pisang (Musa sp.), merupakan salah satu jenis tanaman yang paling banyak terdapat di Indonesia, tetapi masih belum memiliki acuan informasi yang lengkap, baik dari segi fitokimia maupun dari segi farmakologi guna dimanfaatkan secara optimal. Penelitian terdahulu terhadap pisang Musa cavendish dari Filipina, telah berhasil diisolasi salah satu jenis antioksidan yaitu gallokatekin yang kandungannya ternyata lebih banyak terdapat dalam kulit daripada buah. Senyawa antioksidan yang terdapat pada kulit pisang yaitu katekin, gallokatekin, dan epikatekin yang merupakan golongan senyawa flavonoid. Hasil uji pendahulian tentang aktivitas antioksidan pada kulit buah pisang mas, pisang raja, dan pisang ambon menunjukkan bahwa kulit pisang raja memiliki aktivitas antioksidan yang paling kuat (Pane, 2013). Ekstrak kulit pisang mengandung 21,33 $\mathrm{mg}$ asam galat $/ \mathrm{kg}$ sampel (Dawanaka, et al., 2015).

Berdasarkan fenomena tersebut, maka perlu dilakukan penelitian untuk mengetahui potensi epigallocatechin gallate kulit pisang raja (Musa paradisiaca var. Raja) terhadap caspase 3 melalui granzyme B pathway pada mencit (Mus musculus) model sepsis berbasis in silico.

\section{METODE}

Populasi dalam penelitian ini adalah epigallocatechin gallate kulit pisang raja (Musa paradisiaca var. Raja). Sampel yang digunakan dalam penelitian ini adalah epigallocatechin gallate kulit pisang raja (Musa paradisiaca var. Raja) berbasis in silico.

\section{Mencari Zat yang Terkandung dalam Kulit Pisang Raja}

Pencarian zat yang terkandung dalam kulit pisang raja dilakukan secara in silico, yaitu menggunakan aplikasi

bioinformatika https://pubchem.ncbi.nlm.nih.gov/, kemudian dipilih salah satu zat yang memiliki kandungan tinggi dan secara tinjauan pustaka dapat berperan dalam penghambatan apoptosis yang terjadi pada sepsis.

PubChem adalah koleksi informasi kimia terbesar yang dapat diakses secara bebas di dunia. Bahan kimia dapat dicari berdasarkan nama, rumus molekul, struktur, dan pengidentifikasi lainnya. Sifat kimia dan fisik, aktivitas biologis, informasi keselamatan dan toksisitas, paten, kutipan literatur, dan lainnya juga dapat ditemukan pada aplikasi ini.

PubChem adalah database kimia terbuka di National Institutes of Health (NIH). Sejak diluncurkan pada 2004, PubChem telah menjadi sumber informasi kimia penting bagi para ilmuwan, mahasiswa, dan masyarakat umum. Setiap bulan situs web dan layanan terprogram menyediakan data untuk beberapa juta pengguna di seluruh dunia.

PubChem sebagian besar menjelaskan mengenai molekul kecil, tetapi juga molekul yang lebih besar seperti nukleotida, karbohidrat, lipid, peptida, dan makromolekul yang dimodifikasi secara kimia. PubChem mengumpulkan informasi tentang struktur kimia, pengidentifikasi, sifat kimia dan fisik, aktivitas biologis, paten, kesehatan, keselamatan, data toksisitas, dan banyak lainnya.

\section{Mencari Potensi Epigallocatechin Gallate}

Pencarian potensi epigallocatechin gallate pada kulit pisang raja dilakukan secara in silico dengan menggunakan aplikasi bioinformatika http://www.pharmaexpert.ru/passonline/. PASS Online memprediksi lebih dari 4000 jenis aktivitas biologis, termasuk efek farmakologis, mekanisme aksi, efek toksik dan merugikan, interaksi dengan enzim metabolisme dan transporter, pengaruh pada ekspresi gen, dan sebagainya.

Profil aktivitas biologis yang diprediksi untuk senyawa yang dibutuhkan dapat didapatkan, namun hanya formula struktural yang diperlukan. Dengan demikian, prediksi dimungkinkan bahkan untuk struktur virtual yang dirancang dalam komputer tetapi belum disintesis. Prediksi didasarkan pada analisis struktur dengan hubungan aktivitas untuk lebih dari 250.000 zat aktif biologis termasuk obat-obatan, kandidat obat, timbal, dan senyawa beracun.

Keakuratan rata-rata prediksi yang diperkirakan dalam prosedur validasi in leave-one-out cross (setiap senyawa dikecualikan dari rangkaian pelatihan dan aktivitasnya diprediksi berdasarkan model SAR yang diperoleh pada bagian lain dari rangkaian pelatihan) untuk seluruh rangkaian pelatihan PASS adalah tentang $95 \%$.

Algoritma Robustness of PASS telah ditunjukkan dalam percobaan khusus dengan senyawa utama dari basis data MDDR yang terdiri dari 18977 senyawa dengan 124 aktivitas. Himpunan senyawa adalah 50 kali dibagi secara acak menjadi dua himpunan bagian yang sama. Subset pertama digunakan sebagai set pelatihan, yang kedua sebagai subset evaluasi dan sebaliknya (100 percobaan). 20, 40, 60, 80\% dari informasi (data aktivitas/struktur) secara acak dikeluarkan dari perangkat pelatihan. Keakuratan prediksi rata-rata (IAP) dihitung untuk setiap jenis kegiatan. Itu menunjukkan bahwa, meskipun penghapusan hingga $60 \%$ dari informasi, PASS masih memberikan akurasi prediksi yang wajar.

Karena layanan PASS digunakan oleh ahli kimia obat, farmakologis dan toksikologi selama beberapa tahun, ada banyak publikasi di mana prediksi PASS dikonfirmasi oleh sintesis selanjutnya dan pengujian biologis. Untuk memberikan prediksi yang lebih akurat untuk senyawa yang termasuk kelas kimia baru dan untuk memperluas area yang dapat diprediksi ke aktivitas biologis baru, PASS secara permanen bekerja pada pembesaran set pelatihan PASS. 


\section{Menganalisis Potensi Epigallocatechin Gallate terhadap Mencit}

Analisis potensi epigallocatechin gallate terhadap mencit dilakukan dengan menggunakan aplikasi http://stitch.embl.de/. STITCH adalah database interaksi yang diketahui dan diprediksi antara bahan kimia dan protein. Interaksi meliputi asosiasi langsung (fisik) dan tidak langsung (fungsional); data STITCH berasal dari prediksi komputasi, dari transfer pengetahuan antara organisme, dan dari interaksi yang dikumpulkan dari database (primer) lainnya.

\section{Menganalisis Mekanisme Epigallocatechin Gallate Kulit Pisang Raja terhadap Caspase 3 pada Mencit Model Sepsis}

Analisis mekanisme epigallocatechin gallate kulit pisang raja terhadap capase 3 pada mencit model sepsis menggunakan aplikasi bioinformatika https://www.kegg.jp/. KEGG adalah sumber daya basis data untuk memahami fungsi dan utilitas tingkat tinggi dari sistem biologis, seperti sel, organisme dan ekosistem, dari informasi tingkat molekuler, terutama dataset molekuler skala besar yang dihasilkan oleh sekuensing genom dan throughput tinggi lainnya teknologi eksperimental.

Analisis hasil pengujian berbagai parameter tersebut dilakukan dengan dua cara yaitu:

\section{Pendekatan Teoritis}

Data yang diperoleh dianalisis dengan cara dibandingkan dengan tinjauan teori dan penelitian sebelumnya yang mendukung hasil penelitian.

\section{Pendekatan in Silico}

Data yang diperoleh dari penelitian ini seluruhnya adalah berbasis in silico, aplikasi bioinformatika yang digunakan dalam penelitian ini adalah https://pubchem.ncbi.nlm.nih.gov/,

http://www.pharmaexpert.ru/passonline/,

http://stitch.embl.de/, dan https://www.kegg.jp/.

\section{HASIL DAN PEMBAHASAN}

Jumlah dari kulit pisang cukup banyak, yaitu kirakira 1/3 dari buah pisang yang belum dikupas. Kandungan unsur gizi kulit pisang cukup lengkap, seperti karbohidrat, lemak, protein, kalsium, fosfor, zat besi, vitamin $\mathrm{B}$, vitamin $\mathrm{C}$, dan air. Unsur-unsur gizi inilah yang dapat digunakan sebagai sumber energi dan antibodi bagi tubuh manusia. Kulit pisang mengandung berbagai jenis komponen yang dapat dimanfaatkan yang dapat dilihat di Tabel 1, 2, dan 3. Kulit buah memiliki kandungan nonnutrisi, termasuk polifenol, flavonoid (Lee, et.al., 2010). Senyawa polifenol ditemukan di sebagian besar jaringan buah (Baskar, et.al., 2011). Pada sebuah penelitian, didapatkan kandungan polifenol pada kulit pisang kering, dengan menggunakan pelarut air, metanol, aseton, dan etanol, di mana pelarut air memiliki efisiensi paling tinggi sebagai pelarut, kemudian diikuti dengan metanol, aseton, dan etanol.
Tabel 1. Komposisi Karbohidrat pada Kulit Pisang

\begin{tabular}{cc}
\hline Sumber Karbon & Konsentrasi \\
\hline Glukosa $(\mathrm{nmol} \mathrm{L}$ & -1 \\
Fruktosa $\left(\mathrm{nmol} \mathrm{L}^{-1}\right)$ & 2,4 \\
Sukrosa $\left(\mathrm{nmol} \mathrm{L}^{-1}\right)$ & 6,2 \\
Maltosa $\left(\mathrm{nmol} \mathrm{L}^{-1}\right)$ & 2,6 \\
Pati $\left(\mathrm{nmol} \mathrm{L}^{-1}\right)$ & 0 \\
Selulosa $\left(\mathrm{nmol} \mathrm{L}^{-1}\right)$ & 1,2 \\
Gula total $\left(\mathrm{nmol} \mathrm{L}{ }^{-1}\right)$ & 8,4 \\
Lignin $(\%)$ & 29 \\
Pektin $(\%)$ & $6-12$ \\
Hemiselulosa $(\%)$ & $10-21$ \\
\hline
\end{tabular}

Sumber: Jamal, et.al., 2012

Tabel 2. Komposisi Mineral pada Kulit Pisang

\begin{tabular}{cc}
\hline Elemen & Konsentrasi $\left(\mathbf{m g ~ g}^{-\mathbf{1}}\right)$ \\
\hline Potasium & $78.10 \pm 6.58$ \\
Kalsium & $19.20 \pm 0.00$ \\
Sodium & $24.30 \pm 0.12$ \\
Besi & $0.61 \pm 0.22$ \\
Manganase & $76.20 \pm 0.00$ \\
Bromin & $0.04 \pm 0.00$ \\
Rubidium & $0.21 \pm 0.05$ \\
Strontium & $0.03 \pm 0.01$ \\
Zirkonium & $0.02 \pm 0.00$ \\
Niobium & $0.02 \pm 0.00$ \\
\hline
\end{tabular}

Sumber: Anhwange, 2008

Tabel 3. Komposisi Antinutrien dari Kulit Pisang

\begin{tabular}{cc}
\hline Parameter & Konsentrasi \\
\hline Moisture $(\%)$ & $06.70 \pm 02.22$ \\
Ash $(\%)$ & $08.50 \pm 1.52$ \\
Organic matter $(\%)$ & $91.50 \pm 0.050$ \\
Protein $(\%)$ & $00.90 \pm 0.250$ \\
Minyak mentah $(\%)$ & $01.70 \pm 0.100$ \\
Karbohidrat $(\%)$ & $59.00 \pm 1.360$ \\
Serat kasar $(\%)$ & $31.70 \pm 0.250$ \\
Hidrogen sianida $(\mathrm{mg} / \mathrm{g})$ & $01.33 \pm 0.100$ \\
Oksalate $\left(\mathrm{mg} \mathrm{g}^{-1}\right)$ & $00.51 \pm 0.140$ \\
Fitat $\left(\mathrm{mg} \mathrm{g}^{-1}\right)$ & $00.28 \pm 0.06$ \\
Saponin $\left(\mathrm{mg} \mathrm{g}^{-1}\right)$ & $24.00 \pm 0.270$ \\
\hline
\end{tabular}

Sumber: Anhwange, 2008

Flavonoid terdapat dalam berbagai bagian dari pisang (Imam, et.al., 2011). Kulit buah pisang masak yang berwarna kuning kaya akan senyawa flavonoid, serta mengandung senyawa fenolik lainnya. Fenol merupakan metabolit sekunder pada tanaman dan diketahui memiliki berbagai kegunaan terapeutik, seperti antioksidan, antimutagenik, antikarsinogenik, mengangkut radikal bebas, dan juga menurunkan komplikasi kardiovaskular (Atun, et.al., 2010; Baskar, et.al., 2011). Adanya flavonoid dan senyawa fenolik lainnya pada kulit pisang perlu diidentifikasi dan diuji aktivitasnya, sehingga dapat meningkatkan pemanfaatan limbah buah pisang lebih optimal.

Berdasarkan penelitian lain, komposisi antioksidan dan antinutrien dari kulit pisang (per $100 \mathrm{~g}$ ), antara lain adalah: karoten, $\beta$-karoten, vitamin $\mathrm{C}$, tanin, okslalat, oksalat yang larut dalam air, asam fitat, serat 
diet tidak larut, serat diet larut (Nagarajaiah dan Prakash, 2011). Kandungan tanin pada kulit, bertindak terhadap ketersediaan protein yang menurun selama pematangan sebagai akibat dari migrasi polifenol dari kulit ke buah dan degradasi fenol oksidatif olek oksidase dan peroksidase polifenol (Emaga, et.al., 2011). Sebuah penelitian oleh Okorondu, et al. (2010) yang melakukan skrining fitokimia pada pisang yang menunjukkan bahwa kulit pisang mengandung tanin, alkaloid, steroid, saponin, flavonoid, dan karbohidrat. Selain itu pisang juga memiliki kandungan Epigallocatechin gallate (EGCG) yang tinggi.

EGCG adalah komponen bioaktif utama katekin yang sebagian besar hadir dalam berbagai jenis teh. EGCG terkenal dengan spektrum yang luas dari aktivitas biologis sebagai agen anti-oksidatif, anti-inflamasi, dan anti-tumor. Efek EGCG pada mekanisme kematian sel melalui induksi apoptosis, nekrosis, dan autophagy telah dipublikasikan. Selain itu, tindakan anti-proliferasi telah dibuktikan dalam banyak garis sel kanker. Itu juga terlibat dalam modulasi siklooksigenase-2, stres oksidatif dan radang berbagai proses seluler. EGCG telah dilaporkan sebagai target agen yang menjanjikan untuk protein membran plasma, seperti reseptor faktor pertumbuhan epidermal. Selain itu, telah ditunjukkan mekanisme aksi yang mengandalkan penghambatan ERK1/2, p38 MAPK, NF- $\kappa$ B, dan faktor pertumbuhan endotel vaskular. Selanjutnya, EGCG dan turunannya digunakan dalam penghambatan proteasome dan mereka terlibat dalam mekanisme epigenetik. Singkatnya, EGCG adalah konstituen teh yang paling dominan dan bioaktif dan dapat berperan dalam pencegahan kanker (Kwon, et al., 2020).

Nuclear factor $-\mathrm{\kappa B} \quad(\mathrm{NF}-\mathrm{\kappa B})$ terlibat dalam berbagai mekanisme seluler, seperti kematian, pertumbuhan, peradangan, dan respons imun. NF- $\mathrm{NB}$ terutama bertindak sebagai pengatur transkripsi gen dalam menanggapi stres oksidatif. Interaksi dengan EGCG dijelaskan dalam berbagai model sel, baik in vivo dan in vitro. NF- $\mathrm{kB}$ adalah salah satu target yang paling banyak diteliti dalam penelitian kanker dan interaksi dengan jalur ini harus dianggap sebagai topik yang relevan dalam desain pengobatan kanker. Aktivitas penghambatan EGCG pada NF- $\mathrm{BB}$ telah ditunjukkan dalam sejumlah besar studi independen. Studi yang dilakukan dalam keratinosit epidermal manusia normal di mana EGCG digunakan pada konsentrasi yang berbeda untuk memodulasi aktivitas NF- $\mathrm{kB}$, yang mengarah ke efek perlindungan terhadap kaskade negatif yang disebabkan oleh radiasi UV. Ini dianggap sebagai bukti mekanisme aksi teh hijau sebagai agen fotoprotektif. Selain itu EGCG telah terbukti mengurangi secara signifikan peradangan mukosa usus dalam menanggapi cedera, sehingga menghambat produksi faktor inflamasi melalui modulasi ekspresi NF$\kappa \mathrm{B}$ dan gen lain yang terlibat (Bing, et al., 2017).
Aktivasi apoptosis yang dimediasi caspase dilaporkan menjadi ciri khas dari jalur pembunuhan yang dimediasi oleh granzyme B dan Fas oleh Cytotoxic $T$ Lymphocytes (CTLs). Namun, kinetika aktivasi caspase tetap tidak terdefinisi karena ketidakmampuan untuk memantau sel target spesifik apoptosis secara real time. Keterbatasan ini telah diminimalisir dengan mengembangkan uji biosensor baru yang mendeteksi aktivitas spesifik protein kontinyu dalam sel target. Biosensor direkayasa dari luciferase yang diijinkan secara melingkar, dihubungkan secara internal oleh keduanya caspase 3/7 atau granzyme B/caspase 8 situs pembelahan, sehingga memungkinkan aktivasi pada pembelahan proteolitik oleh masing-masing protease. Tingkat aktivasi biosensor caspase 3/7 secara tak terduga cepat mengikuti granzyme $\mathrm{B}$ dibandingkan dengan sinyal yang diperantarai Fas. Dengan sangat baik, sinyal biosensor caspase 3/7 yang bergantung pada Fas yang diinduksi oleh CTL manusia yang kekurangan perforin juga dapat dideteksi setelah 90 menit (Li, et al., 2014).

Limfosit $\mathrm{T}$ sitotoksik sangat penting untuk menghilangkan sel yang terinfeksi virus dan sel ganas dalam tubuh. CTLs membunuh sel-sel target sebagian besar dengan salah satu dari dua metode: 1) persalinan termediasi perforin setelah eksositosis sitotoksik butiran, dan/atau 2) Fas ligand (FasL) - penengah sasaran reseptor kematian sel Fas. Pembentukan sinaps imun antara CTL dan sel target memicu orkestrasi granula yang cepat jalur eksositosis (Jenkins, et al., 2010; Dustin, et al., 2010; de Saint Basile, et al., 2010). Pada sinaps imun, granzymes masuk sel target mengikuti gangguan membran oleh perforin. Itu mekanisme yang tepat tentang bagaimana perforin mengirimkan granzymes ke dalam sel target masih dalam penyelidikan (Praper, et al., 2011; Thiery, et al., 2011; Lopez, et al., 2013).

Sepuluh granzymes telah diidentifikasi pada tikus dan lima pada manusia genom, menunjukkan redundansi. Target granolyme B proteolysis telah dipelajari lebih luas daripada granzymes lainnya. Pembelahan langsung dan aktivasi caspase 3 selanjutnya oleh granzyme B dianggap sebagai langkah kritis pertama yang diinduksi oleh CTL apoptosis. Caspase 3 aktif dapat diukur dalam sel target dengan aliran sitometri, mewakili satu metode dimana fungsi CTL dapat dinilai. Selain itu, fungsi CTL secara rutin diukur dengan kehilangan integritas sel membran target atau bukti degranulasi CTL oleh flowcytometry dan/atau dengan pengukuran sitolisis dengan standar emas, uji lempeng mikro rilis $51 \mathrm{Cr}$. Setiap pendekatan ini menggunakan uji titik akhir. Tidak ada arus metodologi memungkinkan evaluasi kinetotik kinetik, terus-menerus fungsi. Meskipun persalinan yang dimediasi oleh granfor perforin dijelaskan sebagai kejadian awal dan kematian yang diinduksi oleh Fas/FasL dijelaskan seperti yang terjadi terlambat, satu-satunya teknologi yang tersedia untuk mengevaluasi kegiatan ini secara real time 
membutuhkan microchip yang canggih teknologi (Hassin, et al., 2011).

\section{SIMPULAN}

Kesimpulan dari penelitian yang telah dailakukan adalah epigallocatechin gallate (EGCG) kulit pisang raja (Musa paradisiaca var. Raja) dapat dijadikan sebagai kandidat target agen yang menjanjikan untuk protein membran plasma, seperti reseptor faktor pertumbuhan epidermal. Selain itu, telah ditunjukkan mekanisme aksi yang mengandalkan penghambatan ERK1/2, p38 MAPK, NF- $\kappa B$, dan faktor pertumbuhan endotel vaskular. Selanjutnya, EGCG dan turunannya digunakan dalam penghambatan proteasome dan mereka terlibat dalam mekanisme epigenetik.

\section{DAFTAR PUSTAKA}

Anhwange, B.A. (2008) Chemical Composition of Musa sapientum (Banana) Peels. Journal Food Technol, 6 (6): 263-6.

Atun, S., Arianingrum, R., Handayani, S., Rudyansah, \& Garson, M, (2007) Identification and Antioxidant Activity Test of Some Compounds From Methanol Extract Peel of banana (Musa paradisiaca Linn.) Indo. Journal Chem, 7 (1): 8387.

Baskar, R., Shrisakhti, S., Sathyapriya, B., Shyampriya, R., Nithya, R., dan Poongodi, P. (2011) Antioxidant Potential of Peel Extracts of Banana Varieties (Musa sapientum). Food and Nutrition Science Journal, 2: 1128-1133.

Bing X., Xuelei L., Wanwei D., Linlang L., Keyan C. (2017) EGCG Maintains Th1/Th2 Balance and Mitigates Ulcerative Colitis Induced by Dextran Sulfate Sodium through TLR4/MyD88/NF- $\mathrm{B}$ Signaling Pathway in Rats. Can. Journal Gastroenterol. Hepatol. 2017;2017:1-9. doi: 10.1155/2017/3057268.

Dawanaka, M., Suryanto, E., \& Wuntu, A. D. (2015) Efek Ekstrak Fenolik dari Beberapa Limbah Tanaman terhadap Fotoreduksi Fe3+ Menjadi Fe2+. Jurnal MIPA UNSRAT, 4 (1): 10-14.

de Saint Basile, G., G. Me'nasche', and A. Fischer (2010) Molecular mechanisms of biogenesis and exocytosis of cytotoxic granules. Nat. Rev. Immunol. Journal, 10: 568-579.

Dugar, S., Chirag Choudhary,and Abhijit Duggal (2020) Sepsis and septic shock: Guideline-based management. Cleveland Clinic Journal of Medicine, 2020, $87 \quad$ (1) 53-64; DOI: https://doi.org/10.3949/ccjm.87a.18143.

Dustin, M. L., and E. O. Long (2010) Cytotoxic immunological synapses. Immunol. Rev. Journal. 235: 24-34.

Emaga, T.H., Brindelle, J., Agneesens, R., Buldgen, A., Wathelet, B., \& Paquot, M (2011) Ripening Influences Banana and Plantain Peels
Composition and Energy Content. Trop. Anim Health Prod Journal, 43 (1): 1-23.

Ghatage DD, Gosavi SR, Ganvir SM, and Hazarey VK (2013. Apoptosis: Molecular Mechanism. Journal of Orofacial Sciences, 4: 103-107.

Hassin, D., O. G. Garber, A. Meiraz, Y. S. Schiffenbauer, and G. Berke (2011) Cytotoxic T lymphocyte perforin and Fas ligand working in concert even when Fas ligand lytic action is still not detectable. Immunology Journal, 133: 190196.

Imam, M.Z., \& Akter, S (2011) Musa paradisiaca L. and Musa sapientum L.: A Phytochemical and Pharmacological Review. Journal of Applied Pharmaceutical Science Journal, 1(5): 14-20.

Jamal, P., Saheed, O. K., \& Alam, Z (2012) Biovalorization Potential of Banana Peels (Musa sapientum). An Overview Asian Journal of Biotechnology, 4 (1): 5.

Jenkins, M. R., and G. M. Griffiths (2010) The synapse and cytolytic machinery of cytotoxic $\mathrm{T}$ cells. Curr. Opin. Immunol. Journal. 22: 308-313.

Krishnakumari, V. Taniya Mary Binny, Harikrishna Adicherla, and Ramakrishnan Nagaraj (2020) Escherichia coli Lipopolysaccharide Modulates Biological Activities of Human- $\beta$-Defensin Analogues but Not Non-Ribosomally Synthesized Peptides. ACS Omega Journal, 2020, 5, 6366-6375

https://dx.doi.org/10.1021/acsomega.9b03770

Kwon, Oh Sung, Ji Hoon Jung, Eun Ah Shin, Ji Eon Park, Woon Yi Park and Sung-Hoon Kim (2020) Epigallocatechin-3-Gallate Induces Apoptosis as a TRAIL Sensitizer via Activation of Caspase 8 and Death Receptor 5 in Human Colon Cancer Cells. Biomedicines Journal, 2020, 8, 84; doi:10.3390/biomedicines 8040084

Lee, E.H., Yeom, H.J., ha, M.S., \& Bae, D.H (2010) Development of Banana Peel Jelly and Its Antioxidant and Textural Properties. Food Sci. Biotechnol Journal, 19 (2): 449-445.

Li, Jinzhu Li, Sarah K. Figueira, Alexandra C. A. Vrazo, Brock F. Binkowski, Braeden L. Butler, Yasuhiro Tabata, Alexandra Filipovich, Michael B. Jordan, Kimberly A. Risma (2014) Real-Time Detection of CTL Function Reveals Distinct Patterns of Caspase Activation Mediated by Fas versus Granzyme B. Journal Immunol 2014; 193:519528. doi: 10.4049/jimmunol.1301668

Lin Chung-Wei C, Taylor Deborah, A Sita M, Zeindra Bierma, Maher Christoper G (2010) Exercise for Osteoarthritis of the Knee, Physical Therapy. 2010. Journal of the American Physical Therapy, 90, 8: 839-842.

Lopez, J. A., O. Susanto, M. R. Jenkins, N. Lukoyanova, V. R. Sutton, R. H. Law, A. Johnston, C. H. Bird, P. I. Bird, J. C. Whisstock, et al. (2013) Perforin 
forms transient pores on the target cell plasma membrane to facilitate rapid access of granzymes during killer cell attack. Blood Journal, 121: 2659-2668.

Nugrajaiah, S.B., \& Prakash, J. (2011) Chemical Composition and Antioxidant Potential of Peel From Three Varieties of Banana. As Journal Food Ag-Ind, 4 (1): 31-46.

Okorondu, S.I., Mepba, H.D., Okorundu, M.M.O., \& Aririatu, L.E. (2010) Antibacterial Properties of Musa paradisiaca Peel Extract. Durrent Trends in Microbiology Journal, 6: 21-26.

Pane, E. R. (2013) Uji Aktivitas Senyawa Antioksidan dari Ekstrak Metanol Kulit Pisang Raja (Musa paradisiaca Sapientum). Jurnal Valensi, 3 (2): 7681.

Praper, T., A. F. Sonnen, A. Kladnik, A. O. Andrighetti, G. Viero, K. J. Morris, E. Volpi, L. Lunelli, M. Dalla Serra, C. J. Froelich, et al. (2011) Perforin activity at membranes leads to invaginations and vesicle formation. Proc. Natl. Acad. Sci. USA Journal. 108: 21016-21021.

Tambajong RN, Lalenoh DC, Kumaat L. (2014) Profil penderita sepsis di ICU RSUP Prof. Dr. R. D. Kandou Manado periode Desember 2014-2015. Jurnal e-Clinic (eCl), 4 (1).

Thiery, J., D. Keefe, S. Boulant, E. Boucrot, M. Walch, D. Martinvalet, I. S. Goping, R. C. Bleackley, T. Kirchhausen, and J. Lieberman (2011) Perforin pores in the endosomal membrane trigger the release of endocytosed granzyme B into the cytosol of target cells. Nat. Immunol. Journal, 12: 770-777.

Wang, Y. and Peter J. Quinn. (2010) Endotoxins: Lipopolysaccharides of Gram-Negative Bacteria. Sub-cellular Biochemistry Journal, 2010. DOI: 10.1007/978-90-481-9078-2_1

Wittmann, I., Schonefeld, M., Aichele, D., Groer, G., Gessner, A., Schnare, M. (2020) Murine Bactericidal/Permeability-Increasing Protein Inhibits the Endotoxic Activity of Lipopolysaccharide and Gram-Negative Bacteria. Journal Immunol, 2020, 180: 7546-7552. 